PYTHAGORAS: Jurnal Pendidikan Matematika

Volume 10 - Nomor 2, Desember 2015, (129-136)

Available online at: http://journal.uny.ac.id/index.php/pythagoras

\title{
Keefektifan Pembelajaran Menggunakan Pendekatan Problem Posing dan Pendekatan Open-Ended Ditinjau Dari HOTS
}

\author{
Dasih Lelani Nurina ${ }^{1}$, Heri Retnawati ${ }^{2)}$ \\ ${ }^{1}$ Program Studi Pendidikan Matematika, Program Pascasarjana, Universitas Negeri Yogyakarta. Jalan \\ Colombo No. 1, Karangmalang, Yogyakarta 55281, Indonesia. Email: dasih.lelani.nurina@ gmail.com \\ ${ }^{2}$ Pendidikan Matematika, Universitas Negeri Yogyakarta, Jl. Colombo No. 1, Karangmalang, \\ Yogyakarta 55281, Indonesia. Email: retnawati.heriuny1@gmail.com
}

\begin{abstract}
Abstrak
Penelitian ini bertujuan untuk mendeskripsikan keefektifan pembelajaran trigonometri dengan menggunakan pendekatan problem posing dan pendekatan open-ended ditinjau dari HOTS siswa. Penelitian ini merupakan penelitian eksperimen semu. Penelitian ini menggunakan satu kelompok eksperimen dan satu kelompok kontrol. Populasi penelitian ini adalah seluruh siswa kelas X SMA Negeri 3 Bantul. Sampel penelitian sebanyak dua kelas yang dipilih secara acak. Instrumen penelitian yang digunakan adalah instrumen tes HOTS. Data dianalisis menggunakan uji one sample t-test dan two independent sample $t$-test. Hasil penelitian menunjukkan bahwa: pendekatan problem posing efektif ditinjau dari HOTS; pendekatan open-ended efektif ditinjau dari HOTS; Pendekatan open-ended tidak lebih efektif dibandingkan dengan pendekatan problem posing ditinjau dari HOTS.
\end{abstract}

Kata Kunci: problem posing, open-ended, higher order thinking skills (HOTS)

\section{The Effectiveness Using Problem Posing Approach and Open-Ended Approach in Terms of the HOTS}

\begin{abstract}
This study aims to describe the effectiveness of teaching Trigonometry using the Problem Posing Approach and Open-Ended Approach in terms of the HOTS of High School Students. This research was a quasi-experimental. The research population comprised nine classes of Year X student of SMA Negeri 3 Bantul. The sample consisted of two classes that were randomly established. The instruments used in the research was HOTS test. The data analysis techniques consisted of the one sample t-test and two independent sample t-test. The results of the research show that: the problem posing approach is effective in terms of HOTS; the open-ended approach effective in terms of HOTS; and there is no difference in effectiveness between the problem posing approach and open-ended approach in terms of HOTS.
\end{abstract}

Keywords: problem posing, open-ended, higher order thinking skills (HOTS)

How to Cite Item: Nurina, D., \& Retnawati, H. (2015). Keefektifan pembelajaran menggunakan pendekatan problem posing dan pendekatan open-ended ditinjau dari HOTS. PYTHAGORAS: Jurnal Pendidikan Matematika, 10(2), 129-136. Retrieved fromhttp://journal.uny.ac.id/index.php/pythagoras/article/view/9128 


\section{PENDAHULUAN}

Dalam dunia pendidikan ada banyak sekali ilmu-ilmu yang dipelajari, salah satunya adalah matematika. Matematika merupakan ilmu yang dinilai sangat penting dan digunakan dalam berbagai bidang, contohnya teknologi, kesehatan, pertanian, dan lain sebagainya. Seperti uraian dalam lampiran penjelasan Peraturan Menteri Pendidikan Nasional Nomor 22 Tahun 2006 tentang standar kompetensi dan kompetensi dasar mata pelajaran matematika disebutkan bahwa menerapkan matematika sebagai dasar penguasaan kompetensi produktif dan pengembangan diri. Selain itu, dalam Principles and Standards for School Mathematics NCTM (2000, p.66) juga disebutkan bahwa "mathematics is used in science, the social sciences, medicine, and commerce". Penyataan tersebut mengungkapkan bahwa matematika digunakan dalam ilmu pengetahuan, pengetahuan sosial, ilmu kedokteran, dan perdagangan.

Uraian tersebut menggambarkan bahwa matematika merupakan ilmu pengetahuan yang sangat bermanfaat bagi kehidupan dan dalam bidang apapun, sehingga matematika sangat penting untuk dipelajari. Namun demikian, objek matematika yang abstrak dan mengandung banyak simbol maupun istilah matematis seringkali membuat siswa merasa kesulitan untuk dapat mempelajari matematika. Indikasi bahwa matematika masih dinilai sulit salah satunya adalah dari kemampuan berpikir siswa yang masih lemah/kurang khususnya dilihat dari hasil pra penelitian di SMAN 3 Bantul. Berdasarkan pengalaman yang disampaikan guru matematika pada saat pra survei, guru tersebut menceritakan bahwa dalam menyampaikan materi matematika kepada para peserta didik terdapat berbagai kesulitan, khususnya yang berkaitan dengan kemampuan berpikir peserta didik ketika menyelesaikan suatu permasalahan. Salah satu materi di mana peserta didik dinilai kurang berhasil dalam pencapaian nilainya adalah trigonometri, khususnya penerapan trigonometri dalam kehidupan sehari-hari. Selain itu, rata-rata nilai Ulangan Harian pada tahun ajaran 2012/ untuk materi trigonometri hanya mencapai nilai 65,50. Hal ini disebabkan karena peserta didik tidak memahami konsep secara mendalam. Kemampuan berpikir tingkat tinggi siswa SMAN 3 Bantul juga dapat dilihat dari kemampuan siswa menjawab soal pada saat pra survei. Soal tersebut merupakan soal yang mendorong siswa untuk mengasah kemampuan menganalisis dan menyelesaikan sebuah permasalahan. Kemampuan menganalisis merupakan salah satu kemampuan yang tergolong dalam higher order thinking skills (HOTS).

Dari 28 siswa yang terdapat di kelas X.4 SMAN 3 Bantul, 4 siswa menjawab benar, 17 siswa menjawab tinggi pohon salah, 3 siswa salah dalam menentukan nilai $\tan 60^{\circ}, 2$ siswa baru menuliskan apa yang diketahui di soal, dan 2 siswa lainnya tidak menjawab. Selain itu, hasil Ujian Nasional yang belum sesuai dengan harapan menunjukkan bahwa perlunya peningkatan kemampuan berfikir dan latihan serta metode belajar yang tepat untuk dapat membantu meningkatkan prestasi siswa, baik dalam pelajaran matematika ataupun yang lainnya. Kemampuan berfikir erat kaitannya dengan prestasi belajar siswa, khususnya matematika. Kemampuan berpikir sangat diperlukan guna memecahkan berbagai persoalan-persoalan dalam pembelajaran yang senantiasa berubah dan berkembang. Persoalan-persoalan yang semakin berkembang menuntut kemampuan berfikir yang juga semakin tinggi.

Banyak definisi tentang kemampuan berpikir, salah satunya menurut Bloom. Menurut Bloom (1956, p.18), "As the taxonomy is organized, it contains six major classes : (1) to remember; (2) to comprehend; (3) to apply; (4) to analyze; (5) to syntesis; and (6) to evaluate". Bloom mengklasifikasikan kemampuan kognitif menjadi enam tahapan atau enam tingkat yang tersebut tersusun secara hierarkis. Tetapi pada tahun 1994, salah seorang murid Bloom, yaitu Lorin Anderson Krathwohl dan para ahli psikologi aliran kognitivisme memperbaiki taksoomi Bloom agar sesuai dengan kemajuan zaman. Krathwohl (2002, p.215) mengatakan bahwa seperti halnya taksonomi asli, revisi ini merupakan hirarki/tingkatan. Namun, karena revisi ini memberikan bobot yang lebih besar dalam penerapannya, maka Krathwohl melakukan revisi hanya pada ranah kognitif. Hasil perbaikan tersebut baru dipublikasikan pada tahun 2001 dengan nama Revisi Taksonomi Bloom. Revisi tersebut meliputi: (1) remembering (mengingat), (2) understanding (memahami), (3) applying (menerapkan), (4) analyzing (menganalisis), (5) evaluating (menilai), dan (6) creating (mencipta). Tiga urutan pertama dari hierarki yang ditulis oleh Bloom merupakan Lower Order Thinking Skills, sedangkan tiga urutan setelahnya merupakan Higher Order Thinking Skills (HOTS). 
Peningkatan kemampuan berfikir siswa erat kaitannya dengan proses pembelajaran yang terjadi di lingkungan sekolah. Meskipun demikian, apabila guru terampil dalam memaknai materi pelajaran matematika, tidak menutup kemugkinan bahwa kemampuan siswa bisa naik ke tingkat selanjutnya, bahkan sampai tingkat to analyze, to evaluate dan to create. Tiga peringkat paling atas dalam taksonomi Bloom (yaitu menganalisis, mengevaluasi, menciptakan) adalah yang disebut dengan berpikir tingkat tinggi atau HOTS. Begitu pula pada revisi taksonomi Bloom, tiga level pertama merupakan lower order thinking skills, dan tiga level berikutnya merupakan Higher Order Thinking Skills (HOTS). Pada tahap berpikir tingkat tinggi atau Higher Order Thinking Skills siswa cenderung lebih menggunakan logika daripada mengingat dan menghafal rumus, dengan demikian penguasaan konsep akan total dan memungkinkan siswa untuk dapat menyelesaikan masalah matematis yang lebih kompleks. Hal ini menjadi sebuah tantangan bagi guru untuk menciptakan pembelajaran yang berorientasi pada higher order tinking skills. Karakteristik HOTS diungkapkan oleh Conklin (2012, p.14) yang menyatakan karakter HOTS sebagai berikut, "characteristic of higher-order thinking skills encompass both critical thinking and creative thinking". Artinya karakteristik ketrampilan berpikir tingkat tinggi mencakup kemampuan berpikir kritis dan kreatif. Pengembangan ketrampilan berpikir tingkat tinggi peserta didik akan menghasilkan: kemahiran peserta didik dalam strategi pemecahan masalah menjadi baik, tingkat keyakinan peserta didik dalam matematika meningkat, dan prestasi belajar peserta didik pada masalah non-rutin yang menuntut ketrampilan berpikir tingkat tinggi meningkat (Butkowski,et al, 1994, p.5)

Guru perlu memberikan stimulus kepada siswa agar siswa dapat mengembangkan kemampuannya. Stimulus tersebut dapat berupa pertanyaan-pertanyaan yang membangun, soalsoal yang dapat membangkitkan kemampuan berpikir tingkat tinggi siswa, maupun pendekatan pembelajaran yang mendukung siswa untuk berpikir tingkat tinggi. Pendekatan yang dapat menstimulus siswa untuk mengembangkan kemampuan berpikir tingkat tinggi diantaranya adalah pendekatan problem posing dan pendekatan open-ended.

Menurut Ellerton dalam Christou (1999, p.1), Problem posing adalah pembuatan soal oleh siswa yang dapat mereka pikirkan tanpa pembatasan apapun baik terkait isi, maupun konteksnya. Pembelajaran dengan pendekatan problem posing adalah pendekatan pembelajaran yang menekankan pada kemampuan siswa mengajukan permasalahan dari informasi yang disajikan oleh guru. Hal ini seperti diungkapkan oleh Silver (1997, p.76) yang meyebutkan bahwa, "problem posing or problem finding, has long been viewed as a characteristic of creative activity or exceptional talent in many fields of human endeavor". Dalam dunia pendidikan, problem posing merupakan salah satu pendekatan pembelajaran yang memiliki peran penting dalam proses pembelajaran matematika. Hal ini sesuai yang dikatakan oleh Lavy \& Shriki (2007, p.129), "Problem posing is an important component of the mathematics curriculum, and is considered to be an essential part of mathematical doing. Dari pernyataan tersebut dapat dipahami bahwa problem posing atau pembuatan masalah/soal telah lama dipandang sebagai karakteristik kegiatan kreatif di berbagai bidang usaha manusia. Salah satu bidang usaha tersebut adalah pelajaran matematika. Arikan \& Unal (2015, p.1) juga menyatakan bahwa problem posing merupakan kegiatan yang dapat digunakan dalam proses pembelajaran matematika. Dari proses inilah siswa dinilai dapat mengembangkan kemampuan berpikir tingkat tingginya karena dalam pengajuan permasalahan tersebut, siswa cenderung berpikir secara kritis yang bisa dimulai dengan pertanyaan "what if not?" atau "what happen if...". Misalnya apabila diketahui amplitudo dari grafik fungsi trigonometri yang persamaanya $y=\sin x$ adalah 1 . Maka soal-soal yang dapat disusun dari pengetahuan sebelumnya diantaranya adalah "bagaimana jika persamaan grafiknya $y=\sin 2 x$ atau $y=2 \sin x$, berapakah amplitudonya?", dan seterusnya.

Hashimoto (1997, p.1) menyatakan bahwa satu metode yang disebut pendekatan openended merupakan pendekatan yang diawali dengan masalah yang tidak lengkap dan pembelajaran dilaksanakan dengan menggunakan berbagai pendekatan untuk menyelesaikan masalah untuk memberikan pengalaman dalam menemukan sesuatu yang baru melalui penggabungan pengetahuan sebelumnya.Pendekatan open-ended adalah pendekatan yang menyajikan masalah terbuka yang memungkinkan siswa mengembangkan pola pikirnya secara terbuka dan bebas sesuai dengan minat dan kemampuan masing-masing. Menurut Shimada (2007, p.1), 
pembelajaran open-ended dapat menstimulasi kreativitas, kemampuan berpikir original, dan inovasi dalam matematika. Selain itu pendekatan open-ended juga menyediakan pengalaman bagi siswa untuk dapat menemukan sesuatu yang baru. Pembelajaran dengan pendekatan open-ended biasanya dimulai dengan memberikan masalah terbuka kepada siswa. Takahashi (2006, p.5). Dengan menggunakan soal terbuka, pembelajaran matematika dapat dirancang sedemikian sehingga lebih memberikan kesempatan kepada siswa untuk mengembangkan kompetensi mereka dalam menggunakan ekspresi matematik.

Misalnya pada soal pembuktian identitas trigonometri. Dalam menjawab soal pembuktian, siswa bebas menggunakan rumus dasar yang mereka pikir dapat membantu menyelesaikan soal. Siswa juga dapat membuktikan identitas trigonometri dari ruas kiri agar sama dengan rass kana, ataupun sebaliknya. Kegiatan pembelajaran harus membawa siswa dalam menjawab permasalahan dengan banyak cara dan mungkin juga banyak jawaban (yang benar) sehingga mengundang potensi intelektual dan pengalaman siswa dalam proses menemukan sesuatu yang baru.

Problem posing dan open-ended berdasarkan karakteristiknya dipandang dapat membantu proses belajar siswa.Karena hal tersebut, maka peneliti merasa tertarik untuk menyelidiki keefektifan dari kedua pendekatan pembelajaran tersebut, yaitu pendekatan problem posing dan pendekatan open-ended ditinjau dari higher order thinking skills (HOTS) pada siswa Sekolah Menengah Atas.

Berdasarkan beberapa penjelasan tersebut terlihat bahwa pendekatan problem posing dan pendekatan open-ended dapat dijadikan sebagai salah satu upaya untuk menjadikan pembelajaran di kelas lebih efektif dan mencapai tujuan pembelajaran serta meningkatkan kemampuan berpikir siswa, khususnya HOTS. Sehingga pada penelitian ini peneliti bertujuan untuk mendeskripsikan keefektifan pembelajaran matematika pokok materi trigonometri dengan pendekatan problem posing dan pendekatan openended ditinjau dari HOTS Selain itu untuk mendeskripsikan mana yang lebih efektif antara pembelajaran matematika pokok materi trigonometri dengan pendekatan problem posing dan pendekatan open-ended ditinjau dari HOTS.

Selain bertujuan untuk mendeskripsikan beberapa hal yang telah disebutkan sebelumnya, penelitian ini juga memiliki beberapa manfaat praktis yang dapat diambil dari penelitian ini, diantaranya adalah siswa memperoleh pengalaman belajar matematika dengan suatu pendekatan problem posing dan pendekatan openended, siswa memperoleh fasilitas belajar berupa LKS yang mengacu pada pendekatan problem posing dan pendekatan open-ended, selain itu kedua pendekatan ini dapat dijadikan alternatif pembelajaran oleh guru guna meningkatkan pembelajaran matematika di kelas khususnya dalam meningkatkan HOTS.

\section{METODE}

Populasi penelitian adalah seluruh siswa kelas X SMA Negeri 3 Bantul yang terdiri atas enam kelas. Sedangkan subjek penelitian ini adalah siswa kelas X.4 dan X.6 yang ditentukan dengan cara acak. Bantul Tahun Ajaran 2013/ 2014 yang masing-masing kelas terdiri atas 28 siswaPenelitian ini merupakan penelitian eksperimen semu dengan desain penelitian pretestposttest nonequivalen control group design. Pada desain ini terdapat dua kelompok yaitu kelompok yang menerapkan pendekatan problem posing dan kelompok yang menerapka pendekatan open-ended. Adapun teknik pengumpulan data yang digunakan dalam penelitian ini adalah mengumpulkan data sebelum diberikan perlakuan yaitu dengan memberikan pretest HOTS yang meliputi kemampuan menganalisis, mengevaluasi, dan mencipta; melakukan tindakan penelitian dengan memberikan perlakuan pendekatan problem posing dan pendekatan open-ended; dan mengumpulkan data setelah diberikan perlakuan pada kelas problem posing dan open-ended dengan memberikan posttest HOTS yang meliputi kemampuan menganalisis, mengevaluasi, dan mencipta. Berikut merupakan reliabilitas dari ketiga instrumen tersebut. Dari segi validitas isi, instrumen tes dan angket layak digunakan menurut ahli. Reliabilitas tes HOTS dengan Standar Error Measurement (SEM) sebesar 0,823 dengan SEM sebesar 2,023.

Teknik analisis data yang digunakan dalam penelitian ini adalah analisis deskriptif dan inferensial. Analisis deskriptif untuk mendeskripsikan keadaan sebelum dan sesudah diberikan perlakuan pada kedua kelas ditinjau variabel terikatnya. Analisis inferensial dilakukan untuk mengambil kesimpulan berdasarkan data yang telah diperoleh selama proses penelitian berlangsung. Analisis inferensial ini terdiri atas uji keefektifan dan uji komparasi/perbedaan keefektifan pembelajaran matematika pokok 
materi trigonometri dengan menggunakan pendekatan problem posing dan pendekatan open-ended.

Sebelum dilakuan analisis keefektifan perlu diketahui bahwa keefektifan pembelajaran matematika dapat ditentukan berdasarkan kriteria pencapaian tujuan pembelajaran yang ditunjukkan dengan ketuntasan belajar siswa dalam belajar matematika. Siswa dikatakan tuntas belajar ketika rata-rata kelas lebih dari atau sama dengan KKM 65, sehingga peneliti menetapkan kriteria efektif untuk variabel HOTS jika siswa sudah mencapai nilai 65 .

Data-data yang diperoleh selama penelitian berlangsung harus memenuhi uji asumsi terlebih dahulu sebelum melalui proses analisis. Uji asumsi yang harus dipenuhi adalah uji normalitas univariat dengan menggunakan uji Kolmogorov-Smirnov dengan taraf signifikansi $5 \%$. Apabila nilai signifikansi yang diperoleh lebih dari 0,05, maka dapat dikatakan bahwa data berdistribusi normal. Berikut hasil uji normalitasnya.

Tabel 1 Hasil Uji Normalitas Univariat

\begin{tabular}{cccc}
\hline \multirow{2}{*}{ Kls } & \multirow{2}{*}{ Variabel dependen } & Sebelum & Setelah \\
\cline { 3 - 4 } & & Sig & Sig \\
\hline Kls X.4 & \multirow{2}{*}{ HOTS } & 0,507 & 0,072 \\
X.6 & & 0,517 & 0,475 \\
\hline
\end{tabular}

Tabel 1 menunjukkan bahwa nilai signifikansi kedua kelas semuanya lebih dari 0,05. Jadi data berdistribusi normal. Selain itu, homogenitas kedua kelompok di uji dengan menggunakan uji uji Lavene's.. Jika nilai signifikansi yang diperoleh lebih dari 0,05, maka varians kedua populasi tersebut homogen. Berikut hasil uji homogenitasnya.

Tabel 2 Hasil Perhitungan Homogenitas Varian Sebelum dan setelah Treatment

\begin{tabular}{ccc}
\hline & Sebelum perlakuan & Setelah Perlakuan \\
\hline $\mathrm{F}$ & 0,812 & 1,051 \\
Sig. & 0,371 & 0,357 \\
\hline
\end{tabular}

Hasil uji asumsi homogenitas menunjukkan bahwa nilai signifikansi lebih dari 0,05, jadi data berasal dari varians yang homogen. Setelah melewati proses uji asumsi, maka dilanjut dengan uji One sample t-test dengan nilai signifikansi 0,05 untuk menganalisis keefektifan dari pendekatan problem posing dan pendekatan open-ended ditinjau dari HOTS. Sementara itu, analisis perbedaan keefektifan antara pendekatan problem posing dan pendekatan open-ended dilakukan dengan uji two independent sample t-test. dengan taraf signifikansi 0,05. Uji ini digunakan untuk melihat apakah pendekatan open-ended lebih efektif dibandingkan dengan pendekatan problem posing.

\section{HASIL DAN PEMBAHASAN}

\section{Hasil Penelitian}

Hasil penelitian ini terdiri atas hasil uji keefektifan dan uji perbandingan keefektifan antara kelompok kelompok eksperimen yang menggunakan pendekatan problem posing dan pendekatan open-ended. Hasil uji keefektifan dengan menggunakan one sample t-test akan disajikan pada Tabel 1.

Tabel 3. Hasil Analisis One Sample t-Test

\begin{tabular}{cccc}
\hline Variabel & Kelas & $\mathbf{t}_{\text {hitung }}$ & $\mathbf{t}_{\text {tabel }}$ \\
\hline \multirow{2}{*}{ HOTS } & Problem Posing & $-0,047$ & \multirow{2}{*}{2,05} \\
& Open-Ended & 1,727 & \\
\hline
\end{tabular}

Berdasarkan hasil perhitungan tersebut terlihat bahwa pendekatan problem posing memiliki nilai $t_{\text {hitung }}=-0,047$. Nilai $t_{\text {hitung }}$ tersebut lebih besar dari nilai $-t_{\text {tabel }}$. Ini berarti pendekatan problem posing efektif ditinjau HOTS. Begitu pula dengan pendekatan openended memiliki nilai $t_{\text {hitung }}=1,727$. Nilai $t_{\text {hitung }}$ tersebut lebih besar dari nilai $-t_{\text {tabel }}$. Ini berarti pendekatan open-ended efektif ditinjau HOTS. Setelah melakukan uji keefektifan, maka dilanjutkan dengan menguji perbedaan keefektifan antara pendekatan problem posing dengan pendekatan open-ended dengan menggunakan uji two independent sample t-test. Hasil perhitungan tersebut menunjukkan bahwa $t_{\text {hitung }}$ $=1,256<\mathrm{t}_{\text {tabel }}=2,004879$, jadi pembelajaran dengan menggunakan pendekatan open ended tidak lebih efektif dibandingkan dengan pendekatan pembelajaran problem posing ditinjau dari HOTS siswa.

Hal ini sesuai dengan hasil analisis deskriptif yang menunjukkan bahwa rata-rata pada kelas open-ended dan problem posing, keduany tidak jauh berbeda. Berdasarkan hasil analisis despritif juga menunjukkan bahwa pembelajaran matematika dengan pendekatan problem posing dan open-ended berdampak positif terhadap HOTS siswa. Hal ini terlihat dari kondisi awal siswa sebelum dan sesudah diberikan perlakuan. Pada kondisi awal di kelas problem posing nilai rata-rata siswa hanya mencapai 34,52. Begitu pula di kelas openended, nilai rata-rata siswa hanya mencapai 


\section{Pythagoras, 10 (2), Desember 2015 - 134}

Dasih Lelani Nurina, Heri Retnawati

37,77.Namun begitu setelah diberikan treatment pada kedua kelas dengan masing-masing pendekatan, hasilnya cukup memuaskan. Pada kelas problem posing rata-rata siswa meningkat menjadi 67,86 dan pada keas openn-ended rata-rata siswa juga menngkat menjadi 73,21. Berikut adalah hasil analisis deskriptif dari kedua kelas.

Tabel 4. Rerata Kelas Problem Posing dan Open-ended

\begin{tabular}{ccc}
\hline \multirow{2}{*}{ Deskripsi } & \multicolumn{2}{c}{ HOTS } \\
\cline { 2 - 3 } & Pre & Post \\
\hline Problem posing & 35,52 & 67,86 \\
Open-ended & 37,77 & 73,21 \\
\hline
\end{tabular}

\section{Pembahasan}

Hasil uji one sample t-test menunjukkan bahwa pendekatan problem posing efektif ditinjau dari HOTS siswa, begitu pula dengan pendekatan open ended. Pendekatan open-ended juga efektif ditinjau dari HOTS. Hasil penelitian ini senada dengan beberapa teori yang menyebutkan bahwa kedua pendekatan ini efektif ditinjau dari berbagai aspek. Begitu pula dengan Xia (2008, p.1) mengatakan bahwa hasil penelitian menunjukkan bahwa model pembelajaran problem posing ini memberikan peran penting dalam membangkitkan minat siswa dalam matematika, meningkatkan kemampuan mereka untuk menumbuhkan pertanyaan akan suatu masalah dan meningkatkan kemampuan mereka dalam belajar matematika. Pendekatan problem posing efektif ditinjau dari kemampuan berpikir tingkat tinggi. Hal ini disebabkan karena pendekatan ini mampu mengarahkan siswa untuk menemukan sesuatu yang baru dalam membuat masalah. Setelah siswa diberi masalah dan solusi yang dicontohkan pada awal pembelajaran kemudian siswa diminta untuk membuat masalah yang sejenis, maka munculah peluang bagi siswa untuk menemukan sesuatu yang baru, mereka mengkonstruk kreativitas mereka mulai dari hal yang sederhana, dengan mengubah angka awalnya, atau mengubah kondisi masalah tetapi dengan pola yang sama, atau yang lainnya yang pada proses siswa diberi kesempatan untuk membuat masalah sendiri seperti ini akan muncul rangsangan kepada siswa untuk lebih kreatif. Selain itu problem posing juga mampu menumbuhkan minat belajar siswa terhadap matematika.

Selain pendekatan problem posing, pendekatan open ended juga efektif ditinjau dari kemampuan berpikir tingkat tinggi, hal ini diseabkan karena didalam pembelajaran dengan pendekatan ini siswa terlibat aktif dalam segala proses pembelajaran, mulai dari memahami masalah, menerjemahkan kedalam bentuk matematis, sampai dengan menentukan solusi dari masalah tersebut. Selain itu, dalam pendekatan ini, siswa diberi kebebasan dalam menggali pemahaman yang mereka miliki sesuai kemampuan mereka dalam memahami masalah hingga menentukan solusi dari masalah, hal ini tentu mendorong siswa untuk menemukan suatu hal yang baru yang masing-masing siswa akan berbeda sesuai dengan kemampuan mereka dalam menerjemahkan masalah yang ada. Shimada (1997, p.1) menjelaskan bahwa "pendekatan open-ended dapat memberi kesempatan kepada siswa untuk memperoleh pengetahuan/pengalaman, menemukan, mengenali, dan memecahkan masalah dengan beberapa teknik sehingga cara berpikir siswa dapat terlatih dengan baik". Inprasitha (2006, p.169) menjelaskan bagaimana dalam era ini pendekatan open-ended yang terintegrasi dengan lesson study menjadi pendekatan matematika yang inovatif. Selain itu, penelitian yang dilakukan oleh Enan (2013, p.92) menjelaskan bahwa pendekatan open-ended dan problem posing sama-sama efektif dalam meningkatkan kemampuan berfikir kreatif siswa.

Analisis perbedaan keefektifan antara pendekatan problem posing dan pendekatan open-ended dilakukan dengan uji two independent sample t-test. Dari uji tersebut diperoleh kesimpulan bahwa pendekatan open ended tidak lebih efektif dibandingkan dengan problem posing ditinjau dari kemampuan berfikir tingkat tinggi. Banyak faktor yang berpengaruh yang menyebabkan pendekatan open ended tidak lebih efektif dibandingkan dengan pendekatan problem posing jika ditinjau dari aspek kemampuan berpikir tingkat tinggi., diantaranya seperti pendapat Nohda (1999) yang mengatakan bahwa tujuan dikembangkan pengajaran dengan pendekatan open ended adalah untuk membantu mengembangkan aktivitas yang kreatif dari siswa dan kemampuan berfikir matematis siswa dalam memecahkan masalah. Selain itu kemampuan berpikir matematika siswa dapat berkembang secara maksimal dan pada saat yang sama kegiatan-kegiatan kreatif dari setiap siswa terkomunikasi melalui proses pembelajaran. Begitu pula yang dikatakan oleh Lavy \& Shriki (2007, p.129), bahwa pembelajaran dengan pendekatan problem posing adalah pendekatan pembelajaran yang menekankan pada kemampuan siswa mengajukan permasalahan dari informasi yang 
disajikan oleh guru. Dikarenakan kedua pendekatan mempunyai ciri dan keunggulan yang dimungkinkan memberikan motivasi tersendiri untuk siswa, maka dari itu kedua pendekatan ini jika dibandingkan hasilnya tidak jauh berbeda.

\section{SIMPULAN DAN SARAN}

\section{Simpulan}

Berdasarkan hasil pengujian hipotesis dan pembahasan, dapat diperoleh kesimpulan, yaitu: pembelajaran matematika pada pokok materi trigonometri kelas X SMA Negeri 3 Bantul dengan pendekatan problem posing efektif ditinjau dari Higher Order Thinking Skills; pembelajaran matematika pada pokok materi trigonometri kelas X SMA Negeri 3 Bantul dengan pendekatan open ended efektif ditinjau dari Higher Order Thinking Skills; dan Pendekatan Open ended tidak lebih efektif dibandingkan dengan problem posing pada pembelajaran matematika pada pokok materi trigonometri kelas X SMA Negeri 3 ditinjau Higher Order Thinking Skills.

\section{Saran}

Bagi guru atau peneliti yang ingin meningkatkan kemampuan HOTS khususnya pada materi trigonometri dapat menerapkan pendekatan problem posing dan open-ended. Penerapan dilakukan dengan cara mengintegrasikan langkah-langkah/tahap-tahap problem posing dan open-ended dalam RPP. Selanjutnya disarankan pada peneliti yang berminat untuk menerapkan kedua pendekatan ini pada pokok bahasan yang lain sehingga dapat memberi bukti yang lebih kuat mengenai keefektifan kedua pendekatan tersebut.

\section{Daftar Pustaka}

Arikan, E. E. \& Unal, H. (2015). An investigation of eighth grade students' problem posing skills (Turkey sample). International Journal of Research in Education and Science (IJRES), 1(1), 2330 .

Bloom, B. S. ed. et al. (1956). Taxonomy of educational objectives: Handbook 1, Cognitive Domain. New York: David McKay.

Butkowski, J., et al. (1994). Improving student higher order thinking skills in mathematics. Theses, Mathematics Education Research. Saint Xavier University-IRI, Fied-Based Masters's Program.
Conklin, W. (2012). Higher-order thinking skills to develop $21^{\text {st }}$ century learners. Huntington Beach: Shell Educational Publishing, Inc.

Christou, C. (1999). An Empirical Taxonomy of Problem Posing Processes. Zentralblatt für Didaktik der Mathematik (ZDM) - The International Journal on Mathematics Education. Diambil tanggal 15 Januari 2007 dari http://subs.emis.de/journals/ZDM/zdm053 a4.pdf.

Depdiknas. (2006). Peraturan Pemerintah Nomor 22 Tahun 2006, tentang Standar Isi.

Enan. (2014). Keefektifan pembelajaran matematika dengan pendekatan open ended dan problem posing ditinjau dari kemampuan berpikir kreatif dan kemampuan pemecahan masalah matematis siswa kelas $\mathrm{x}$ administrasi perkantoran smk muhammadiyah bobotsari Tahun 2012/ 2013. Tesis magister tidak diterbitkan, Universitas Negeri Yogyakarta, Yogyakarta.

Hashimoto. (1997). The methods of fostering creativity through mathematical problem solving. Yokohama National University. 86-87.

Inprasitha, M. (2006). Open-ended approach and teacher education. Tsukuba Journal of Education Study in Mathematics, Vol. $25,169-258$.

Krathwohl, D. R. 2002. A Revision of Bloom's Taxonomy: An Review. Theory Into Practice. Volume 41, Number 4. College Education. The Ohio State University.

Lavy, I. \& Shriki, A. (2007). Problem posing as a means for developing mathematical knowledge of prospective teachers. Makalah disajikan pada Proceedings of the $31^{\text {th }}$ Conference of The International Group for the Psychology of Mathematics Education, di Oranim Academic College of Education

NCTM. (2000). Principles and standars for school mathematics. Reston, VA: NCTM

Shimada, S. (1997). The Significance of an open-ended approach. The open-ended approach: A New Proposal for Teaching Mathematics (pp. 1-9). Reston, VA: NCTM. 


\section{Pythagoras, 10 (2), Desember 2015 - 136}

Dasih Lelani Nurina, Heri Retnawati

Silver, E.A. (1997). Fostering creativity through instruction rich in mathematical problem posingand problem posing. Diambil pada tanggal 20 Oktober 2012 dari http://www.fizkarlsruhe.de/fiz/publication /zdm/2dm97343.pdf

Steven, J. (2002). Applied multivariate statistic for the social science. Mahwah, NJ: Lawrence Erlbaum Associate.

Takahashi, A. (2008). Communication as a process for students to learn mathematical. DePaul University. Diambil pada tanggal 17 Februari 2015, dari

http://www.criced.tsukuba.ac.jp/math/ape c/apec2008/.

Xia, X., Lu, C., \& Wang, B. (2008). Research on mathematics instruction experiment based problem posing. Diambil tanggal 02 Agustus 2014, dari http://www.educationinforatoz.org. 